\title{
Pengembangan Budaya Toleransi dalam Pembelajaran PAI di SMA Semen Gresik
}

\author{
A'idatul Fadlilah \\ Institut Keislaman Abdullah Faqih Gresik \\ E-mail: aidatulfadlilah@gmail.com \\ Moch. Bachrurrosyady Amrulloh \\ Institut Keislaman Abdullah Faqih Gresik \\ E-mail: rosyady.edu@gmail.com
}

\begin{abstract}
Abstrak: Pendidikan toleransi menjadi keharusan pada saat ini, khususnya di dunia pendidikan, karena melalui pendidikan inilah nilai-nilai kerukunan menjadi kokoh.sistem pendidikan agama sangat penting dan perlu ditingkatkan, sehingga yang dihasilkan sistem itu bukan orang-orang yang hanya berpengetahuan agama tetapi juga berakhlak mulia. Dengan mengadakan pendidikan agama yang membawa kepada pandangan luas dan sikap terbuka serta mementingkan dan meningkatkan di dalamnya pembinaan kerukunan antar agama diharapkan dapat terwujud dan berkembang dalam masyarakat, maka dari itu Pendidikan toleransi dibutuhkan guna menciptakan kehidupan yang indah dengan banyak perbedaan didalamnya, di SMA Semen Gresik merupakan sekolah swasta yang tidak berlatar agama namun bisa menerima siswanya dari manpun dan dari berbagai latar belakang yang berbeda pula sehingga tidak ada perbedaan diantara mereka. Permasalahan yang dikaji adalah: 1) Bagaimana proses pengembangan budaya toleransi dalam pembelajaran PAI di SMA Semen Gresik 2) Bagaimana output dari proses pengembangan budaya toleransi di SMA Semen Gresik. Hasil penelitian menunjukkan: 1) Proses pengembengan toleransi dalam pembelajaran PAI yakni dengan menggunakan sebuah pendekatan saintifik yang mana didalam pendekatan tersebut terdapat beberapa metode diantaranya pembiasaan, diskusi kelompok2) output dari proses pengembangan tolernasi dalam pembelajaran PAI diantaranya Menghargai perbedaan, menghargai kebaikan orang lain, keterbukaan, senang dan bahagia dalam berinteraksi dengan orang lain, membantu orang tanpa melihat latar belakang mereka yang berbeda, tidak diskriminatif dengan sesama, yang mana telah ada pada diri peserta didik.
\end{abstract}

Kata Kunci: pengembangan, budaya toleransi, Pendidikan Agama Islam.

\begin{abstract}
Tolerance education is a necessity at this time, especially in the world of education in seeding the values of harmony. The religious education system is very important and needs to be improved, so that the resulting system is not people who only have religious knowledge but also have a noble morality. By implementing religious education that brings a broad view and open attitude, emphasizes and increases in it, the development of interfaith harmony is expected to be realized and developed in society. Therefore tolerance education is needed to create a beautiful life littered fully with many differences in it. Senior High School (SMA) Semen Gresik is a private school that has no religious background but could accept students from anywhere and various different backgrounds so that there is no difference between them. The problems studied are: 1) How is the process of developing a culture of tolerance in SMA Semen Gresik 2) What is the output of the process of developing a culture of tolerance in SMA Semen Gresik.
\end{abstract}


The results show that: 1) The process of developing tolerance in SMA Semen Gresik is by using a scientific approach with such methods as habituation and group discussion, 2) The output of the process of developing tolerance in SMA Semen Gresik includes respect for differences, respect for the kindness of others, openness, frendly and happy in interacting with other people, helping people regardless of their different backgrounds, not discriminating others.

Keywords: development, culture of tolerance, Islamic Religious Education.

\section{Pendahuluan}

Keberagaman adalah suatu hal yang tak dapat dihindari dari kehidupan di muka bumi ini. Banyak sekali perbedaan dan keberagaman yang sering kita temukan di sekeliling kita. Terutama bagi kita yang hidup dan tinggal di Negara Indonesia, negara yang memiliki semboyan "Bhinneka Tunggal Ika, Berbeda-beda tetapi tetap satu jua." Dari semboyan ini kita tahu bahwa Negara Indonesia memiliki banyak sekali keberagaman.

Indonesia adalah negara kepulauan terbesar dengan memiliki pulau terbanyak di dunia, terbentang dari sabang sampai Papua. Sebagai negara bermasyarakat majemuk, pada 2014, Indonesia berpenduduk 250 juta, dengan angka kemajmukan suku, agama, Bahasa, tradisi, dan budaya yang luar biasa. Secara etnoligi terdapat 1.340 suku dari 300 kelompok etnik (suku bangsa), dan 726 bahasa daerah dimana sekitar 300 bahasa daerah yang masih aktif dipakai, serta 6 agama besar yang termaktub dalam konstitusi, yaitu, Islam, Kristen, Katolik, Hindu, Budha dan Konghuchu, serta lebih dari 50-an kepercayaan local. ${ }^{1}$

Melalui UUD 1945 pasal 29 ayat 2 telah disebutkan bahwa "Negara menjamin kemerdekaan tiap-tiap penduduk untuk memeluk agamanya sendiri-sendiri dan untuk beribadat menurut agamanya dan kepercayaanya". Dengan berbagai macam latar belakang suku, budaya, dan agama yang berbeda-beda seharusnya berbagai unsur ini memahami posisi dan porsinya masing-masing, akan tetapi pada kenyataanya sampai sekarang masih ada masyarakat pada umumnya, dan kaum muslimin pada khususnya, belum memahami batasan toleransi yang baik dan benar sesuai dengan pedoman Al-Qur'an dan Sunnah².

Keragaman dan perbedaan merupakan desain Tuhan (sunatullah) yang tidak dapat dielakkan dari panggung kehidupan,Kehadirannya akan senantiasa ada. Hal ini sebagaimana Firman Allah SWT dalam QS. Al-hujurat : 13

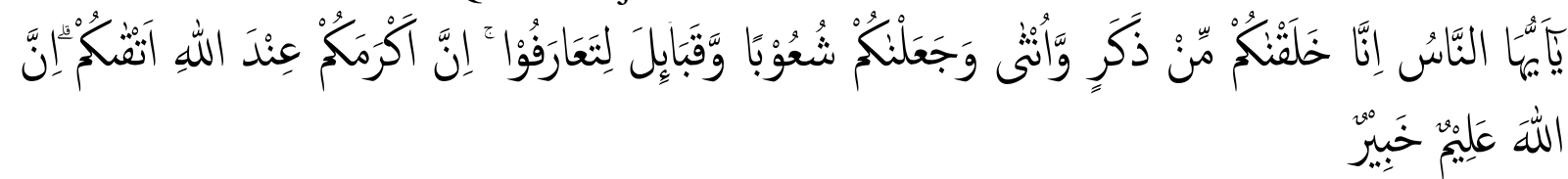

"Hai manusia, sesungguhnya Kami menciptakan kamu dari seorang laki-laki dan seorang perempuan dan menjadikan kamu berbangsa-bangsa dan bersuku-suku supaya kamu saling kenal-mengenal. Sesungguhnya orang yang paling mulia diantara kamu disisi Allah ialah orang yang paling takwa diantara kamu. Sesungguhnya Allah Maha Mengetahui lagi Maha Mengenal." (Qs. Al-Hujurat : 13). ${ }^{3}$

Dalam ayat tersebut, meberikan pemahan kepada kita bahwa Allah SWT menciptakan manusia dari dua hal yang berbeda yakni dari laki-laki dan perempuan. Dan kami jadikan

\footnotetext{
${ }^{1}$ Nurhati Fuad, "Toleransi Beragama Pada Anak Melalui Pendidikan” Societas DEI, Vol. 2, No. 1, (2015), 72.

${ }^{2}$ Muhammad Rifqi Fachrian, Toleransi Antar Umat Beragama dalam al-Qur'an (Depok: PT Raja Grafindo Persada,2018), 1.

${ }^{3}$ Al-Qur'an dan Terjemahanya (Bandung: PT Mizan Pustaka, 2009), 518.
} 
kalian serasi, dari kedua hal tersebut melahirkan keturunan yang berbeda-beda pula, keberbedaan menjadikan manusia mampu membentuk suku-suku yang menjadi manusia yang beragam supaya sebagian dari kalian saling mengenal sebagian yang lain ${ }^{4}$. Karena keragaman tidak dimaksudkan untuk saling meneror, memaksa atau membunuh, Al-Qur'an mengenalkan konsep yang luar biasa, keragaman itu untuk kita saling menganal satu sama lain.

Keragaman itulah terkadang memunculkan konflik yang diakibatkan oleh perbedaanperbedaan ideologi kelompok semata. Sikap intoleransi dan diskriminasi juga kerap kali terjadi, terutama berkaitan dengan agama.sebagaimana Agus Wibowo menunjukkan, bahwa pendidikan agama dan moral yang berlangsung selama ini masih ada kelemahan. Pendidikan agama sebagai sumber nilai etika dan moral bangsa tidak berdaya sepenuhnya untuk mewarnai kehidupan sehari hari. ${ }^{5}$ Berbagai pendidikan formal dan non formal belum optimal menanamkan sikap toleran peserta didik. Bhineka Tunggal Ika baru sebatas konsep yang tersusun indah dalam lantunan lagu, buku pelajaran dan dokumen kenegaraan. Nilai toleransi untuk hidup rukun, ramah, saling menghargai perbedaan, gotong-royong, saling pengertian, dan kerelaan untuk hidup secara damai dan harmoni ${ }^{6}$ terasa kian memudar dari bangunan kepribadian umat beragama. Sikap intoleransi yang dapat mengarah pada tindakan radikal dan bahkan kekerasan atas nama agama tak hentinya mengancam kemajemukan umat dan bangsa Indonesia hingga sekarang. ${ }^{7}$

kemajemukan tersebut apabila tidak dikelola dan dibina dengan tepat dan baik akan menjadi pemicu dan penyulut konflik dan kekerasan yang dapat menggoyahkan sendi-sendi kehidupan berbangsa. Peristiwa Ambon dan Poso, misalnya, merupakan contoh kekerasan dan konflik horizontal yang telah menguras energi dan merugikan tidak saja jiwa dan materi tetapi juga mengorbankan keharmonisan antar sesama masyarakat Indonesia. ${ }^{8}$

Peristiwa tersebut menjadikan kita tahu bahwa degradasi nilai-nilai toleransi dari prespektif agama maupun ras, etnik, budaya dan suku, menjadi sebuah masalah bersama bangsa Indonesia dan masalah kemanusiaan pada umumnya. Upaya untuk meminimalisasi degradasi tersebut dapat dilakukan dengan mengembangkan nila-nilai toleransi dalam Pendidikan. Dengan harapan Pendidikan dijadikan mediasi dalam melerai konflik intern umat beragama yang terjadi melalui transfer nilai toleransi dalam mengarahkan peserta didik untuk menghargai keberagaman. ${ }^{9}$

Menurut Anik Farida, bahwa dewasa ini telah banyak lembaga pendidikan sekolah dan madrasah yang melakukan pendidikan toleransi keagamaan. Hanya saja intensitas masingmasing lembaga pendidikan dalam mengembangkan pendidikan toleransi keagamaan

\footnotetext{
${ }^{4}$ Abu Ja'far Muhammad bin Jarir Ath Thabhari, Tafsir Ath-Thabari (23), diterjemahkan dari jami' Al-Bayan an Ta'wil Ayi Al-Qur'an, terj Abdurrahman Supandi (Jakarta: Pustaka Azzam, 2009), 767.

5 Agus Wibowo, Pendidikan Karakter-Strategi Membangun Karakter Bangsa Berperadaban (Jakarta: Pustaka Pelajar, 2012), 1 - 24.

${ }^{6}$ Mundzier Suparta, Islamic Multicultural Education (Yogjakarta: Pustaka Pelajar, 2008)55 - 58

${ }^{7}$ Mulyani A. Nurhadi. 2012. Proceeding International Symposium on The Strategic Role of Religious Education in The Development of Culture of Peace. Jakarta: Centre for Research and Development and Training Ministry of Religious Affairs

${ }^{8}$ Martin Van Bruinessen, "Genealogies of Islamic Radicalism in post-Suharto Indonesia", Southeast Asia Research, No. 2, (2002), 117.

${ }^{9}$ Rohmat, Tinjauan Multikultural, 1-2.
} 
berbeda satu sama lain. ${ }^{10}$ Secara nasional pendidikan toleransi tidak ada standar khusus. Pendidikan toleransi diserahkan pada satuan pendidikan masing-masing. Pemerintah hanya memberikan rambu-rambu yang tertuang dalam peraturan perundangan, seperti UndangUndang Nom or 20 Tentang Sisdiknas tahun 2003 dan Peraturan Pemerintah Nomor 19 Tentang Standar Nasional Pendidikan tahun 2005, serta Peraturan Pemerintah Nomor 55 Tentang Pendidikan Agama dan Keagamaan tahun 2007.

Maka dari itu penting akan sebuah toleransi antar umat beragama agar salah satunya tidak ada lagi gesekan antar anggota atau kelompok yang bermotifkan salah satunya mengatasnamakan agama. Di satu sisi, pendidikan mempunyai peran penting untuk membentuk kehidupan sosial yang harmonis. Sehingga dengan pendidikan setiap individu memiliki bekal untuk menjunjung tinggi norma-norma sosial yang berlaku. Makna pendidikan yang hakiki lagi adalah pembinaan akhlak manusia guna memiliki kecerdasan membangun kebudayaan masyarakat yang lebih baik dan mampu meningkatkan kesejahteraan hidupnya. $^{11}$

Pendidikan juga merupakan hak setiap manusia, termasuk hak mendapat pendidikan agama bagi setiap penganut agama yang diakui eksistensinya di Negara Kesatuan Republik Indonesia. Pengelola lembaga pendidikan wajib memberikan pendidikan agama sesuai agama yang dianut siswa. Pendidikan agama merupakan salah satu mata pelajaran wajib yang harus diikuti oleh setiap siswa disekolah pada semua jenjang, yaitu SD, SLTP dan SLTA maupun perguruan tinggi. Secara yuridis, ketentuan ini salah satunya tertuang dalam Udang-undang nomor 20 Tahun 2003 tentang Sistem Pendidikan Nasional (SISDIKNAS), pasal 13 huruf a mengamanatkan: "Setiap peserta didik pada setiap satuan pendidikan berhak mendapatkan pendidikan agama sesuai dengan agama yang dianutnya dan diajarkan oleh pendidik seagama." (UU Sisdiknas, $2010: 170)^{12}$

Sekolah memegang peranan penting dalam menanamkan nilai toleransi pada siswa. Toleransi merupakan sikap yang sangat penting untuk diterapkan dan dikembangkan dalam proses pembelajaran karena dengan melihat beberapa isu SARA (suku, agama, ras, dan antargolongan) yang terjadi di Indonesia saat ini, sikap toleransi memang harus di ajarkan bahkan di terapkan sejak dini, agar pemahaman terhadap toleransi dapat di aktualisasikan, serta dapat terbiasa dengan situasi dan kondisi apapun.

Khususnya dalam hal ini Pendidikan Agama Islam memberikan peran penting dalam pengembangan jiwa toleransi dikalangan peserta didik. Pendidikan Agama Islam dapat berfungsi menjadi dasar pembentukan akhlakqul karimah yaitu akhlak terpuji diantaranya toleransi, adil, demokrasi dan menghormati perbedaan. Nilai-nilai yang terkandung dalam Pendidikan Agama Islam juga selaras dengan nilai yang dikembangkan dalam pendidikan multikultural. Begitu juga seorang pendidik, guru/dosen Pendidikan Agama Islam (PAI) yang tentunya bertanggung jawab terhadap pemahaman siswa akan toleransi yang baik dan benar, sesuai dengan Al-qur'an dan Sunnah. Hal ini menjadi perhatian dalam dunia Pendidikan, peserta didik yang dihadapi terdiri dari latar belakang yang berbeda, dengan adanya

\footnotetext{
10 Anik Farida et.all, Pendidikan Multikulturalisme Di Sekolah Menengah Atas (Jakarta: Kedeputian Bidang Pengembangan SIPTEKNAS Kementerian Riset dan Teknologi, 2010).

${ }^{11}$ Hasan Basri, Filsafat Pendidikan Islam (Bandung : CV Pustaka Setia,2009), 54

12 Azwarhadi, "Implementasi, pendidikan islam, toleransi beragama" Jurnal Manajemen, Kepemimpinan dan Supervisi Pendidikan, Vol. 1, No. 02 (2016), 31.
} 
pemahaman tentang toleransi, seluruh komponen Pendidikan mampu bersikap, baik sesama Muslim maupun non-Muslim, baik di lingkungan sekolah, maupun masyarakat. ${ }^{13}$

Berdasarkan paparan data diatas maka perlu dilakukan kajian di sekolah yang terdapat keragama budaya dan agama. Dalam hal ini peneliti melakukan riset di SMA Semen Gresik yang merupakan salah satu lembaga sekolah swasta favorit di kota Gresik yang mengutamakan unity in diversity dan juga sekolah yang berprestasi adiwiyata mandiri nasional, sekolah berbasis ramah lingkungan dan ramah dalam interaksi sosial serta unggul tanpa mengesampingkan karakter anak didiknya. SMA Semen Gresik merupakan sekolah yang bersifat general tidak berlatar belakang suku, budaya dan agama tertentu, namun sekolah ini memiliki murid dari berbagai pelosok nusantara, dari sabang hingga papua, Siswa SMA Semen berasal dari lingkungan, kondisi keluarga danlatar belakangagama yang berbeda-beda yaitu terdiri dari Islam, Katolik, Protestan dan Hindu meskipun tidak dipungkiri bahwa siswa muslim masih menjadi kalangan mayoritas.

Demi kelancaran proses pembelajaran agama bagi siswa non-mulim, pihak sekolah melalui kebijakannya menyediakan guru agama yang seagama dengan mereka, waktu khusus, tempat ritus keagamaan sendiri sehingga mereka bisa belajardengan nyaman sesuai dengan keyakinan masing-masing, tidak hanya disitu sekolah ini juga ikut berpartisipasi dengan lembaga yang aktif dibidang pengembangan antar umat beragama dikabupaten Gresik, dengan mengikuti diskusi maupun kegitan extra lainnya seperi halnya paduan suara "Bhira Suara Bhineka" yang diikuti oleh siswa di Gresik yang tidak melihat dari latar belakang mereka yang berbeda, dengan hal itu siswa dapat mendalami arti dari saling menghormati antar sesama pemeluk agama ${ }^{14}$.

\section{Pengembangan Budaya Toleransi dan Konteksnya dalam Ajaran Islam}

Emile Durkheim (1858-1917) dan Marcel Maus (1872-1950) juga menjelaskan kultur atau budaya adalah sekelompok masyarakat yang menganut simbol-simbol yang mengikat dalam sebuah masyarakat untuk diterapkan. Franz Boas (1858-1942) dan A.L Kroeber (18761960) mendefinisikan kultur adalah hasil sebuah sejarah-sejarah khusus umat manusia yang melewatinya secara bersama-sama di dalam kelompoknya. ${ }^{15}$

Koentjaraningrat menyebutkat unsur-unsur dari kebudayaan adalah meliputi: a) Sistem Religi dan upacara keagamaan; b) Sistem dan organisasi kemasyarakatan; c) Sistem pengetahuan; d) Bahasa; e) Kesenian; f) Sistem mata pencarian hidup. ${ }^{16}$

Jadi yang dimaksud pengembangan budaya adalah suatu proses meningkatkan atau mempertahankan kebiasaan yang ada pada masyarakat. Dan dalam kajian pengembangan masyarakat yang menggambarkan bagaimana budaya itu berubah dari waktu ke waktu yang banyak di tunjukkan sebagai pengaruh global. ${ }^{17}$

Sedangkan konsep toleransi berasal dari bahasa Inggris, yaitu : "tolerance" berarti sikap membiarkan, mengakui dan menghormati keyakinan orang lain tanpa memerlukan

\footnotetext{
${ }^{13}$ Muhammad Rifqi Fachrian, Toleransi Antar Umat, 1.

${ }^{14}$ Fauzi, Wawancara, Gresik, 4 Juli 2020.

15 M. Ainul Yaqin, Pendidikan Multikultural, Cross-Cultural Understanding untuk Demokrasi dan keadilan (Yogyakarta: Pilar Media, 2005), 27-28.

${ }^{16}$ Koentjaraningrat, Kebudayaan, Mentalitas dan pembangunan (Jakarta: Gramedia, 1989), 74

17 Jim ife, Frank Teseriero. Cumunity Development (Yogyakarta: Pustaka Belajar, 2006), 447.
} 
persetujuan. Dalam bahasa Arab diterjemahkan dengan " tasamuh", berarti saling mengizinkan, saling memudahkan. ${ }^{18}$

Dalam hal ini toleransi juga diartikan sebagai pemberian kebebasan kepada sesama manusia atau kepada sesama warga masyarakat untuk menjalankan keyakinannya atau mengatur hidupnya dan menentukan nasibnya masing-masing, selama didalam menjalanan dan menentukan sikapnya itu tidak melanggar dan tidak bertentangan dengan syarat-syarat azas syarat terciptanya ketertiban dan perdamaian dalam masyarakat. Toleransi dikatakan sebagai suatu pandangan yang mengakui the right of self determination, yang artinya hak menentukan hak itu, seseorang tidak harus melanggar hak-hak orang lain. ${ }^{19}$

Selanjutnya, pengertian toleransi menurut Kemendiknas yaitu sikap dan tindakan yang menghargaiperbedaan agama, suku, etnis, pendapat, sikap, dan tindakan orang lain yang berbeda dari dirinya. Pendapat kemendiknas tersebut menjelaskan bahwa toleransi yaitu sikap saling menghargai setiap perbedaan yang ada diantara masyarakat yang satu dengan masyarakat yang lainnya. Dengan adanya sikap toleransi, diharapkan masyarakat Indonesia dapat hidup berdampingan diantara perbedaan yang ada. ${ }^{20}$

Toleransi dalam Islam dikenal dengan istilah tasamuh yang berarti juga toleran. Islam sangat menghargai perbedaan. Banyak ayat Al-Qur`an yang memberi ruang kepada nilai-nilai toleran Dan dalam keadaan apapun, bagaimanapun dan kapanpun saja, Islam adalah sebagai agama rahmatallil"alamin senantiasa menghargai dan menghormati perbedaan, baik perbedaan suku, bangsa, dan keyakinan. Hal sangat ini jelas, bahwa Islam selalu memberikan kebebasan berbicara dan toleransi beragama terhadap semua pemeluk agama dan berkeyakinan serta rasa hormat. $^{21}$

Sikap toleran juga mengajarkan untuk saling mengenal dan menghormati bukanlah saling merendahkan sebagaimana tertuang dalam al-Qur'an surat Al-Hujurat 11. Allah berfirman:

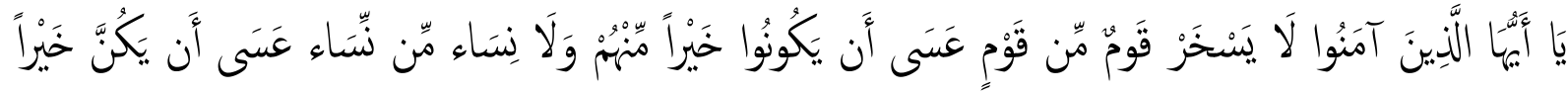

Artinya: "Wahai orang-orang yang beriman! Janganlah suatu kaum mengolok-olok kaum yang lain, (karena) boleh jadi mereka (yang diperolok-olokkan) lebih baik dari mereka (yang mengolok-olok), dan jangan pula perempuan-perempuan (mengolok-olokkan) perempuan lain, (karena) boleh jadi perempuan (yang diperolok-olokkan) lebih baik dari perempuan (yang mengolok-olok).”(Al-Hujurat 11) ${ }^{22}$

Toleransi dan kerukunan hidup yang tercipta di dalam hidup manusia merupakan faktor yang sangat urgen dan srategis, tanpa adanya toleransi dan kerukunan hidup hubungan antar

\footnotetext{
${ }^{18}$ Sa'id Agil Husin Al Munawar, Fiqih Hubungan Antar Agama (Jakarta: Ciputat Press), 13 .

19 Umar Hasyim, Toleransi dan kemerdekaan Beragama dalam Islam Sebagai dasar Munuju Dialog dan Kerukunan Antar Agama (Jakarta: PT. Bina Ilmy. 1978), 22.

${ }^{20}$ Kemendiknas. Bahan Pelatihan Penguatan Metodologi Pembelajaran Berdasarkan NilaiNilai Budaya untuk Membentuk Daya Saing dan Karakter Bangsa (Jakarta: Kementerian Pendidikan Nasional Badan Penelitian dan Pengembangan Pusat Kurikulum, 2010), 25.

${ }^{21}$ Abu Bakar, "Konsep Toleransi Beragama dan Kebebasan Beragama” Jurnal: Toleransi Beragama: Media Komunikasi Umat Bergama, Vol.7, No.2 (2015), 44.

${ }^{22}$ Al-Qur'an Dan Terjemahanya (Bandung : PT Mizan Pustaka, 2009), 518.
} 
manusia akan menjadi rawan dan mudah terganggu, dan gangguan ini akan mengakibatkan terjadinya ketidak teraturan dan kedaiaman hidup. ${ }^{23}$

Perlu dijelaskan juga bahwa toleransi yang diperbolehkan yakni yang tidak dalam hubungan manusia dengan Tuhan, tidak berhubungan dengan peribadatan. Tapi yang diperbolehkan toleransi dalam hubungan sesama manusia yang terlepas dari unsur-unsur peribadatan tersebut. Contoh toleransi yang tidak dibenarkan, karena merasa simpati atau sungkan, ikut berpartisipasi atau ikut beribadat sesuai tata cara peribadatan yang mereka anut. Contoh toleransi yang diperbolehkan yakni saling bertegur sapa, tetap berbuat baik dan tetap saling menghormati. Dalam Islam sendiri terdapat jenis-jenis toleransi diantaranya adalah sebagai berikut:

1. Toleransi dalam hal aqidah atau keyakinan

Prinsip Kebebasan beragama bukan berarti pembenaran terhadap agama lain. Kebebasan tersebut merupakan hak setiap orang dan fitrah manusia dari Tuhan, karena tabiat manusia adalah menuhankan sesuatu. Oleh karena itu dalam agama Islam tidak dibenarkan pemaksaan sebuah keyakinan (iman) mengingat pembentukan keyakinan harus dilakukan seseorang secara sadar dengan kerelaan hati dan penuh tanggung jawab. Bahkan selain memberi kebebasan beragama Islam juga memberi kebebasan untuk tidak beragama sama sekali atau atheis. Namun perlu diketahui bahwa setiap pilihan tentu ada konsekuensinya masing-masing. Jadi, prinsip kebebasan beragama dalam Islam merupakan fitrah dan hak setiap manusia dari Tuhan untuk dipertangung jawabkan masing-masing.

2. Toleransi dalam Ibadah (ritual keagamaan)

Ritual dalam setiap agama tentu dari bentuk dan caranya berbeda-beda. Selain tata cara yang beragam, tempat dan waktu peribadatan pun berbeda. Meskipun beberapa ada persamaan, namun sejatinya memiliki esensi yang tidak sama karena semuanya berangkat dari ajaran dan keyakinan yang berbeda. Dengan demikian sebagai umat beragama harus memahami bahwa masing-masing agama mempunyai ajaran berbeda-beda dalam tata cara peribadatan. Semua itu merupakan ciri khas dan kepribadian umat beragama itu sendiri. Oleh karena itu tidak diperbolehkan mencampur adukkan ajaran agama-agama. Dalam hal ini masing-masing agama harus mempunyai sikap setuju dalam perbedaan.

3. Toleransi dalam hubungan sosial

Sebagai makhluk sosial manusia tentunya tidak akan bisa hidup sendiri. Kehidupan sosial tersebut tidak dapat dipisahkan dari agama Islam meskipun dalam hal ini umat Islam bisa bersikap lebih inklusif kepada umat agama lain dengan berpegang teguh pada ketentuan yang ada. Pergaulan dan interaksinya dalam sosial umat agama lain tidak dilarang sepanjang tidak bertentangan dengan control tersebut. Islam memberi penekanan pada umat nya untuk berbuat baik, menyebarkan kasih sayang, saling membantu dan berbuat adil. Semua itu tidak dilaksanakan atau ditunujukkan kepada umat muslim saja bahkan non muslim juga. Karena toleransi antar umat beragama dalam mualamah duniawi memang dianjurkan supaya tolong menolong, hidup dalam kerukunan tanpa memandang perbedaan agama, suku, bahasa dan ras. ${ }^{24}$

Berdasarkan pengertian-pengertian tentang toleransi di atas, dapat disimpulkan bahwa toleransi ialah sikap menerima dan menghargai perbedaan-perbedaan yang ada serta tidak melakukan diskriminasi terhadap kaum minoritas. Perbedaan yang dimaksud meliputi perbedaan agama, ras, suku, bangsa, budaya, penampilan, kemampuan dan lain-lain. Tujuan

\footnotetext{
${ }^{23}$ Faisal Islamil, Islam, Identitas, Ilahiyah dan Realitas Insaniyah (Yogyakarta: Tiara Wacana Group, 2009), 195/

${ }^{24}$ Siti Rizki Utami, Implementasi Nilai-Nilai Toleransi dalam lembaga non Muslim (IAIN Salatiga, 2018), 4143.
} 
dari sikap toleransi ini ialah membuat tatanan dunia yang penuh dengan kedamaian, sehingga kefanatikan dan kekejaman tidak dapat ditolerir.

\section{Artikulasi Sikap Toleransi dalam Konteks Sosial dan Keagamaan}

Adapun bentuk-bentuk toleransi ialah sikap saling menghargai tanpa membedakan suku, gender, penampilan, budaya, keyakinan, kemampuan, atau orientasi seksual. Orang yang toleran bisa menghargai orang lain meskipun berbeda pandangan dan keyakinan. Dalam konteks toleransi tersebut, orang tidak bisa mentolerir kekejaman, kefanatikan, dan rasialisme. Bentuk-bentuk sikap toleransi, antara lain: ${ }^{25}$

1. Berlapang dada dalam menerima semua perbedaan, karena perbedaan adalah Rahmat Allah swt.

2. Tidak membeda-bedakan (mendiskriminasi) teman yang berbeda keyakinan.

3. Tidak memaksakan orang lain dalam hal keyakinan (agama).

4. Memberikan kebebasan orang lain untuk memilih keyakinan (agama).

5. Tidak mengganggu orang lain yang berbeda keyakinan ketika mereka beribadah.

6. Tetap bergaul dan bersikap baik dengan orang yang berbeda keyakinan dalam hal duniawi.

7. Menghormati orang lain yang sedang beribadah.

8. Tidak membenci dan menyakiti perasaan seseorang yang berbeda keyakinan atau pendapat dengan kita.

Bentuk-bentuk toleransi yang ada tersebut digunakan untuk menjadi acuan dalam penelitian yang akan dilakukan. Toleransi yang ada dilokasi penelitian mengacu pada bentukbentuk toleransi yang sudah ada. Bentuk-bentuk toleransi untuk membentuk karakter peserta didik yang nantinya akan menjadi karakter yang baik.

Selain itu toleransi mempunyai unsur-unsur yang harus ditekankan dalam mengekspresikannya terhadap orang lain. Unsur-unsur tersebut adalah: ${ }^{26}$

1. Memberikan kebebasan atau kemerdekaan

Dimana setiap manusia diberikan kebebasan untuk berbuat, bergerak maupun berkehendak menurut dirinya sendiri dan juga di dalam memilih suatu agama atau kepercayaan. Kebebasan ini diberikan sejak manusia lahir sampai nanti ia meninggal dan kebebasan atau kemerdekaan yang manusia miliki tidak dapat digantikan atau direbut oleh orang lain dengan cara apapun. Karena kebebasan itu adalah datangnya dari Tuhan YME yang harus dijaga dan dilindungi. Di setiap negara melindungi kebebasankebebasan setiap manusia baik dalam Undang-Undang maupun dalam peraturan yang ada. Begitu pula dalam memilih satu agama atau kepercayaan yang diyakini, manusia berhak dan bebas dalam memilihnya tanpa ada paksaan dari siapapun.

2. Mengakui Hak Setiap Orang

Suatu sikap mental yang mengakui hak setiap orang di dalam menentukan sikap perilaku dan nasibnya masing-masing. Tentu saja sikap atau perilaku yang dijalankan itu tidak melanggar hak orang lain, karena kalau demikian, kehidupan di dalam masyarakat akan kacau.

3. Menghormati Keyakinan Orang Lain

Landasan keyakinan di atas adalah berdasarkan kepercayaan, bahwa tidak benar ada orang atau golongan yang berkeras memaksakan kehendaknya sendiri kepada orang atau

\footnotetext{
${ }^{25}$ Pasurdi Suparlan, Pembentukan Karakter (Bandung: PT Remaja Rosdakarya, 2008), 78.

${ }^{26}$ Maskuri Abdullah, Pluralisme Agama dan Kerukunan dalam Keagamaan (Jakarta: Buku Kompas, 2001$), 13$.
} 
golongan lain. Tidak ada orang atau golongan yang memonopoli kebenaran dan landasan ini disertai catatan bahwa soal keyakinan adalah urusan pribadi masing-masing orang.

4. Saling Mengerti

Tidak akan terjadi, saling menghormati antara sesama manusia bila mereka tidak ada saling mengerti. Saling anti dan saling membenci, saling berebut pengaruh adalah salah satu akibat dari tidak adanya saling mengerti dan saling menghargai antara satu dengan yang lain. ${ }^{27}$

Toleransi mempunyai arti sikap lapang dada seseorang untuk menghormati dan membiarkanuntuk melaksanakan ibadah menurut ajaran dan ketentuan agama masing-masing yang diyakini tanpa ada yang mengganggu atau memaksakan baik dari orang lain maupun dari keluarganya sekalipun.

\section{Pengembangan Budaya Toleransi dalam Pembelajaran PAI}

Pembelajaran adalah proses interaksi peserta didik dengan pndidik dan sumber belajar pada suatu lingkungan belajar. Pembelajaran merupakan bantuan yang diberikan pendidik agar dapat terjadi proses peolehan ilmu dan pengetahuan, penguasaan kemahiran dan tabiat, serta pembetukan sikap dari kepercayaan pada peserta didik. Dengan kata lain, pembelajaran adalah proses untuk membantu peserta didik agar dapat belajar dengan baik.

"Istilah pendidikan berasal dari kata "didik" dengan memberinya awalan "pe" dan akhiran "kan" mengandung arti" perbuatan". Istilah pendidikan ini semula berasal dari bahasa Yunani, yaitu" paedagogie yang berarti bimbingan yang diberikan kepada anak. lstilah ini kemudian diterjemahkan kedalam bahasa Inggris dengan"education" yang berarti pengembangan/bimbingan". ${ }^{28}$

Pendidikan menurut John Dewey adalah proses pembentukan kecakapan-kecakapan fundamental secara intelektual dan emosional ke arah alam dan manusia. ${ }^{29}$

Dalam undang-undang nomor 20 tahun 2003 tentang sistem pendidikan nasional, di jelaskan bahwa pendidikan adalah: "satu upaya dan terencana untuk mewujudkan suasana belajar da proses pembelajaran agar peserta didik secara aktif mengembangkan potensi dirinya untuk memiliki kekuatan spiritual keagamaan, pengendalian diri, kepribadian, Kecerdasan, ahlak mulia, serta keterampilan yang diperlukan dirinya masyarakat, bangsa dan Negara (pasal 1 ayat 1). ${ }^{30}$

Agama adalah sistem yang mengatur tata keimanan (kepercayaan) dan peribadatan kepada tuhan yang maha kuasa serta tata kaidah yang behubungan dengan pergaulan manusia serta lingkungannya. ${ }^{31}$

Maka dari itu Pendidikan Agama Islam adalah suatu proses pengembangan potensi kreatifitas peserta didik, bertujuan untuk mewujudkan manusia yang beriman dan bertakwa kepadaA Allah SWT terampil, memiliki etos kerja yang tinggi berbudi pekerti luhur, mandiri dan bertanggung jawab terhadap dirinya, bangsa, dan negara serta agama. ${ }^{32}$

\footnotetext{
${ }^{27}$ Ibid., 202

${ }^{28}$ Ramayulis, Ilmu Pendidikan Islam, Cet ke-3 (Jakarta: KalamMulia,2002), 1.

${ }^{29}$ Hasbullah, Dasar-dasar Ilmu Pendidikan (Jakarta : Rajawali Pers, 2009), 2.

${ }^{30}$ Undang-Undang Nomor 20 Tahun 2003 Tentang Sistem Pendidikan Nasional, Pasal 1 Ayat 1

${ }^{31}$ Ali Mudlofir, Modul Pengembangan Profesionalitas Guru (Jakarta,2011), 41.

${ }^{32}$ Arief Armai, Pengantar Ilmu dan Metodologi Pendidikan Islam (Jakarta: Ciputat Pres, 2002), 3-8.
} 
Pendidikan Agama Islam juga lebih menekankan pada pembenahan perilaku, baik bagi dirinya sendiri maupun bagi orang lain. Jadi dalam proses pembelajaran tidak hanya bersifat teoritis saja akan tetapi bersifat praktis juga, didalam ajaran Islam tidak memisahkan antara iman dan amal saleh. Karena ajaran Islam berisi tentang ajakan sikap dan tingkah laku pribadi masyarakat menuju kesejahteraan hidup perorangan dan bersama.

Maka Pendidikan Agama Islam (PAI) merupakan usaha sadar dan terencana untuk menyiapkan siswa dalam meyakini, memahami, menghayati dan mengamalkan ajaran agama Islam melalui kegiatan bimbingan, pengajaran dan atau latihan. Pendidikan Agama Islam yang pada hakikatnya merupakan sebuah proses itu, dalam pengembangannya juga dimaksud sebagai rumpun mata pelajaran yang diajarkan di sekolah maupun perguruan tinggi. Dengan demikian, Pendidikan Agama Islam (PAI) dapat dimaknai dalam dua pengertian yang pertama sebagai proses penanaman suatu ajaran agama Islam dan yang kedua sebagai bahan kajian yang menjadi materi dari proses penanaman atau pendidikan itu sendiri. ${ }^{33}$

Disamping itu, jika diperhatikan lebih mendalam, Islam juga memuat ajaran-ajaran yang sejalan dengan nilai-nilai pendidikan multikultural. ${ }^{34}$

1. Nilai Kesamaan (al-sawiyah)

Nilai kesamaan ini memandang manusia pada dasarnya sama derajatnya. Adapun satusatunya pembedaan kualitatif dalam pandangan Islam adalah ketakwaan. Menurut Islam, seluruh manusia berasal dari suatu asal yang sama, yaitu nabi Adam dan Hawa.

2. Nilai Keadilan (al-'adalah)

Nilai keadilan ini mampu membongkar budaya nepotisme dan sikap-sikap korup, baik dalam politik, ekonomi, hukum dan kewajiban, bahkan dalam praktek-praktek keagamaan.

3. Nilai Kebebasan dan Kemerdekaan (al-hurriyah)

Nilai ini memandang semua manusia pada hakikatnya hamba Tuhan saja, sama sekali bukan hamba sesama manusia. Dalam pandangan Islam, nilai kebebasan ini menempatkan semua manusia pada hakikatnya sebagai hamba Tuhan saja, sama sekali bukan hamba sesama manusia. Artinya, manusia mempunyai kemerdekaan dalam segala hal, seperti profesi, memilih hobi, memilih wilayah hidup, bahkan dalam menentukan pilihan agama sekalipun adalah suatu kebebasan.

4. Nilai Toleransi (tasamuh)

Toleransi ini erat kaitannya dengan perbedaan, dimana toleransi ini dimaknai sebagai kemampuam untuk menghormati sifat dasar, keyakinan, dan perilau yang dimiliki oleh orang lain. Toleransi juga dipahami sebagai sifat atau sikap menghargai, membiarkan, atau membolehkan pendirian (pandangan) orang lain yang bertentangan dengan pandangan kita.

Dari pemaparan-pemaparan tersebut diperoleh satu gambaran yang menegaskan islam telah mengajarkan pada umatnya tentang persamaan hak dan kewajiban bagi setiap warga negara serta tidak adanya diskriminasi yang mengatasnamakan ras, suku, ataupun agama.

\section{Budaya Toleransi dalam Pembelajaran PAI: Bentuk dan Metodenya}

Pendidikan toleransi menjadi keharusan pada saat ini, khususnya di dunia pendidikan, karena melalui pendidikan inilah nilai-nilai kerukunan menjadi kokoh. Menurut Harun Nasution, pendidikan dan pembinaan akhlak mulia dalam sistem pendidikan agama dipentingkan dan perlu ditingkatkan, sehingga yang dihasilkan sistem itu bukan orang-orang

\footnotetext{
33 Nazarudin, Manajemen Pembelajaran (Implementasi Konsep, karakteristik dan metodologi Pendidikan Agama Islam di Sekolah Umum) (Yogyakarta: Teras, 2007), 12.

${ }^{34}$ Alwi Shihab, Islam Inklusif: Menuju Sikap Terbuka dalam Beragama, Cet. Ke-3 (Bandung: Mizan, 1998$), 41$.
} 
yang hanya berpengetahuan agama tetapi juga berakhlak mulia. Dengan mengadakan pendidikan agama yang membawa kepada pandangan luas dan sikap terbuka serta mementingkan dan meningkatkan di dalamnya pembinaan kerukunan antar agama diharapkan dapat terwujud dan berkembang dalam masyarakat. ${ }^{1}$ Dalam hal ini SMA Semen Gresik adalah sekolah swasta satu-satunya di kota Gresik yang tidak berlatar belakang agama dan terdiri dari berbagai macamsuku manapun. Namun mampu mengedepankan toleransi dan karakter disekolah, SMA Semen Gresik juga telah melaksanakan kurikulum yang ideal yakni kurikulum 2013 yang dijadikan pedoman untuk menerapkan pendidikan Islam yang menanamkan nilai toleransi di SMA Semen Gresik.

Dengan demikian pembelajaran pengembangan nilai-nilai toleransi dalam pendidikan Islam telah dijalankan secara baik di SMA Semen Gresik, dalam pengembangan nilai-nilai pendidikan Islam yang toleransi, SMA Semen Gresik juga sudah menerapkan beberapa prinsip toleransi yang mana adalah suatu tanda bahwa terdapat sikap dan suasana toleransi di antara sesama manusia, maka prinsip-prinsip tersebut adalah sebagai berikut ${ }^{2}$ :

\section{Mengakui Hak Setiap Orang}

Suatu sikap mental yang mengakui hak setiap orang didalam menentukan sikap dan nasibnya masing-masing. tentu saja sikap atau prilaku yang dijalanlkan itu tidak melanggar hak orang lain, karena demikian, kehidupan di dalam masyarakat akan kacau. Udangundang nomor 20 Tahun 2003 tentang Sistem Pendidikan Nasional (SISDIKNAS), pasal 13 huruf a mengamanatkan: "Setiap peserta didik pada setiap satuan pendidikan berhak mendapatkan pendidikan agama sesuai dengan agama yang dianutnya dan diajarkan oleh pendidik seagama." (UU Sisdiknas, $2010: 170)^{3}$

Yang mana sekolahSMA Semen Gresik telah membuka diri untuk siapa saja yang ingin belajar di SMA Semen Gresik. Keterbukaan ini pada akhirnya menjadikan SMA Semen Gresik memiliki warna yang beraneka ragam di dalamnya. aspek daerah asal siswanya, SMA Semen Gresik memiliki siswa yang berasal dari berbagai penjuru nusantara, tentunya tiap daerah memiliki suku dan budaya yang berbeda antara satu sama lain. Kemudian adanya siswa yang beragama non muslim semakin menambah daftar perbedaan yang ada di SMA Semen Gresik, hal ini SMA Gresik telah menerapkan dan mengambangkan prinsip tersebut yaitu mengakui hak setiap orang.

2. Menghormati Keyakinan Orang Lain

Landasan keyakinan diatas adalah berdasarkan kepercayaan, bahwa tidak benar ada orang atau golongan yang bersikeras memaksakan kehendaknya sendiri kepada orang lain atau golongan lain. SMA Semen Gresik selalu menghormati dan menghargai segala hasil usaha atau karya siswa dan siswinya, tidak melihat latar belakang dari segi apapun. Salah satunya banyak prestasi yang tengah ditorehkan oleh siswa-siswi SMA Semen Gresik baik dalam hal prestasi akademik maupun non akademik. Dan sekolah sangat menunjang prestasi tersebut dengan melayani setiap kebutuhan dan keinginan para siswanya, tidak membedakan dari mana asal siswa tersebut, beragama apa siswa tersebut, selagi prestasi itu

\footnotetext{
${ }^{1}$ Harun Nasution, Islam Rasional Gagasan Dan Pemikiran (Bandung: Mizan 1998), 269.

${ }^{2}$ Umar Hasyim, Toleransi Dan Kemerdekaan Beragama Dalam Islam sebagai Dasar Menuju Dialog dan Kerukunan Antar Agama (Surabaya : PT.Bina Ilmu, 1991), 23-25

3 Azwarhadi, "Implementasi, Pendidikan Islam, Toleransi Beragama" Jurnal manajemen, kepemimpinan dan supervisi pendidikan, Vol. 1, No. 2 (2016), 27.
} 
diperoleh, siapapun pasti akan mendapat apresiasi dari sekolah. SMA Semen Gresik sangat mengerti bahwa segala prestasi disekolah tersebut tidak akan mudah diperoleh, jika kita hanya mempermasalahkan latar belakang dari siswa-siswi tersebut.

\section{Agree in Disagrement}

Agree in Disagrement (setuju di dalam perbedaan) adalah prinsip yang selalu didengungkan oleh mentri Agama Pof. DR. H. Mukti Ali. Perbedaan tidak harus ada permusuhan, karena perbedaan selalu ada di dunia ini, dan perbedaan tidak harus menimbulkan pertentangan.Nampak juga pada sekolah SMA Semen Gresik Dari segi interaksi siswa, sikap saling setuju akan perbedaan dalam menghargai satu sama lain begitu mudah dilakukan di sekolah ini, siswa maupun siswinya tidak memandang dari sudut pandang perbedaan.

3. Saling mengerti

Tidak akan terjadi saling menghormati antara sesama orang bila mereka tidak ada saling mengerti. Saling anti dan saling membenci, saling berebut pengaruh adalah salah satu akibat dari tidak adanya saling mengerti dang saling menghargai antara satu dengan yang lain. Dengan demikian toleransi menyangkut sikap jiwa dan kesadaran hati seseorang. Kesadaran jiwa menimbulkan kejujuran dan kepolosan sikap-prilaku. Dari semua prinsipprinsip yang telah disebutkan di atas itu, falsafah pancasila telah menjamin adanya ketertiban dan kerukunan hidup bermasyarakat. ${ }^{4}$

Prinsip toleransi merupakan prinsip yang sangat dominan dari penerapan nilai-nilai pendidikan Islam di SMA Semen Gresik, mayoritas siswa di SMA Semen Gresik yang didominasi oleh agama Islam, tidak lantas membuat dikotomi antar sesama siswanya. Semua siswa bersahabat menjalin kebersamaan dengan sangat baik dan tidak nampak terdapat perbedaan yang terjadi dilingkungan tersebut. Peran guru dalam memberntuk siswa dalam bingkai prinsip tersebut, menjadikan siswa di SMA Semen Gresik begitu baik dalam berinteraksi sosial, tidak banyak terlihat perselisihan yang berkaitan dengan perbedaan latar belakang.

Untuk merealisasi tujuan dan fungsi pendidikan yang dapat menumbuhkan sikap toleransi beragama pada peserta didik, pendidikan di sekolah harus menekankan penanaman nilai-nilai toleransi beragama dalam pembelajaran PAI .Metode yang dipilih oleh pendidik dalam pembelajaran tidak boleh bertentangan dalam pembelajaran. Metode harus mendukung kemana kegiatan interaksi edukatif berproses guna mencapai tujuan. Tujuan pokok pembelajaran adalah mengembangkan kemampuan anak secara individu agar bisa menyelesaikan segala permasalahan yang dihadapinya. ${ }^{5}$

Dalam proses pembelajaran pengembangan toleransi terdapat metode yang digunakan diantarnya adalah:

\section{Metode keteladanan}

Metode yang diterapkan dengan cara meberi contoh-contoh teladan yang baik yang berupa prilaku nyata. Khususya ibadah dan akhlak.

2. Metode pembiasaan

\footnotetext{
${ }^{4}$ Umar Hasyim, Toleransi dan Kemerdekaan Beragama, 23-25.

${ }^{5}$ Ismail SM, Strategi Pembelajaran PAI Berbasis PAIKEM (Semarang: Rasail, 2009), 17.
} 
Segala sesuatu yang sengaja dilakukan secara berulang-ukang, agar sesuatu itu dapat menjadi kebiasaan. Metode ini berinitikan pengalaman. Karena yang dibiasakan itu ialah sesuatu yang diamalkan. Dan inti dari pembiasaan adalah pengulangan. Digunakan untuk membiasakan melakukan prilaku terpuji

3. Metode Spontanitas

Metode menuangkan kata atau tulisan maupun berbicara secara langsung, tanpa persiapan, yang hanya mengandalkan pengalaman maupun pengetahuan.

4. Metode pengkondisian

Pengkondisian dilakukan dengan penciptaan kondisi yang mendukung keterlaksanaan pendidikan karakter.

5. Kegiatan rutinitas

Kegiatan yang terus-menerus dilakukan secara teratur dan konsistenj untuk mencapai tujuan tertentu.

6. Pengintegrasian dalam mata pelajaran.

Penggabungan aktivitas program(mata pelajaran), atau komponen perangkat yang berbeda ke dalam satu unit fungsional. ${ }^{6}$

Berikut juga terdapat teori model pengembangan toleransi dalam pembelajaran agama Islam. $^{7}$

1. Model investigasi kelompok

Model ini dirancang untuk membimbing para siswa mendefinisikan masalah, mengeksplorasi berbagai cakrawala mengenai masalah itu, mengumpulkan data yang relevan, mengembangkan dan mengetes hipotesis

2. Model bermain peran

Model ini dirancang oleh Fanie dan Heotge Shaftel (1984). Khususnya untuk membantu siswa mempelajari nilai-nilai dan moral dan pencerminannya dalam prilaku. Disamping itu model ini digunakan pula untuk membantu para siswa mengumpulkan dan mengorganisasikan isu-isu moral dan sosial, mengembangkan emphaty terhadap orang lain, dan burupaya memperbaiki keterampilan sosial.

3. Model Penelitian Yusrisprudensi

Model ini menerapkan motode studi kasus dalam proses peradilan dan menerapkannya dalam suasana belajar disekolah. Dalam model ini pelajar dilibatkan dalam masalahmasalah sosial misalnya tentang konflik moral, intoleransi dan sikap-sikap sosial lainnya.

Hal inilah, penulis dapat merefleksikan atas hasil wawancara selama dalam penelitian tentang proses pengembangan toleransi dalam pembelajaran Pendidikan agama Islam di SMA Semen Gresik. Dari paparan diatas Nampak bahwa SMA Semen Gresik memiliki tujuan, pendekatan serta pembentukan karakter nilai pendidikan toleransi yang sesuai dengan teori pengembangan diatas, beberapa kegiatan yang syarat akan keberagaman dan nilai-nilai toleransi di SMA Semen Gresik. Dimana teori tersebut memunculkan teori baru tentang pengembangan toleransi dalam pembelajaran pendidikan Islam di SMA Semen Gresik yakni

\footnotetext{
${ }^{6}$ Zainul Akhyar, Harpani Matnuh, Siti Patimah. "Implementasi Toleransi Antar Umat Beragama Di Desa Kolam Kanan Kecamatan Barambai Kabupaten Barito Kuala”, Jurnal Pendidikan Kewarganegaraan, Vol. 5 (Mei, 2015), 728.

${ }^{7}$ Saripuddin, U. W. Konsep dan Strategi Moral Pancasila di Sekolah Menengah (Jakarta: Depdikbud Dirjen Dikti, 1998), 99.
} 
hal tersebut terpolakan sebagai berikut: dengan menggunakan pendekatan saintifik. Gambaran mengenai pendekatan saintifik dalam proses pengembangan toleransi dalam pembelajaran PAI berikut langkah-langkahnya:

\section{Mengamati}

Siswa melihat lembar kerja materi makna hadist yang berkaitan dengan toleransi. Selain itu dengan pemberian contoh-contoh materi makna hadis yang berkaitan dengan toleransi untuk dikembangkan peserta didik, dari media interaktif lainnya

2. Menanya

Siswa mengajukan pertanyaan berkaitan dengan toleransi yang tidak dapat dipahami untuk mendaptkan informasi tambahan tentang apa yang diamati guna untuk mengembangkan kreativitas rasa ingin tahu, kemampuan merumuskan pertanyaan untuk membentuk pikiran kritis

3. Mengumpulkan Informasi

Siswa mecatat semua informasi tentang materi toleransi yang berkaitan dengan toleramsi yang telah diperoleh pada buku catatan dengan tulisan yang rapi.

4. Mengelola Informasi

Dari materi yang berkaitan dengan toleransi yang sudah dikumpulkan dari hasil informasi yang didapat, informasi tersebut diolah dengan bantuan pertanyaan pada lembar kerja

5. Kesimpulan (mengkomunikasikan)

Memberi kesimpulan dari hasil kerja dengan berupa kesimpulan berdasarkan hasil analisis secara lisan, tertulis, atau media lainnya untuk mengembangkan sikap jujur, teliti, toleransi.

Kemampuan berfikir sistematis, mengungkapkan pendapat dengan sopan yang mana dalam pendekatan saintifik tersebut didalamnya terdapat metode tanya jawab maupun berdiskusi secara kecil maupun kelompok.

Dengan latar belakang yang berbeda dan melalui proses pembelajaran pengembangan toleransi dikelas tersebut, sehingga pelaksanaan pendidikan islam mengenai, toleransi, keadilan dan keseimbangan tersebut dapat diimplementasikan, karena suasana kelas yang beragam menuntut kepedulian antar sesama didalamnya, tanpa harus memikirkan dari mana asalnya, apa sukunya, apa agamanya. Tujuan mereka hanya satu yaitu sebuah pendidikan yang dapat menjadikan mereka menjadi siswa yang beradab, beretika dan mencapai kesuksesan dalam hidup di dunia maupun akhirat kelak.

\section{Penutup}

Dari hasil penelitian tentang proses tentang pengembangan budaya toleransi dalam pembelajaran PAI di SMA Semen Gresik dapat kami simpulkan bahwa SMA Semen Gresik dalam menerapkan nilai-nilai pendidikan toleransi didasarkan pada beberapa prinsip: Pertama Mengakui hak setiap orang, Suatu sikap mental yang mengakui hak setiap orang didalam menentukan sikap dan nasibnya masing-masing. Kedua, Menghormati keyakinan orang lain, landasan keyakinan diatas adalah berdasarkan kepercayaan, bahwa tidak benar ada orang atau golongan yang bersikeras memaksakan kehendaknya sendiri kepada orang lain atau golongan lain. ketiga Agree in Disagrement, Agree in Disagrement (setuju di dalam perbedaan) adalah prinsip yang selalu didengungkan oleh mentri Agama Mukti Ali. Perbedaan tidak harus ada permusuhan, karena perbedaan selalu ada di dunia ini, dan perbedaan tidak harus menimbulkan pertentangan, Kelima Saling mengerti, tidak akan terjadi saling menghormati 
antara sesama orang bila mereka tidak ada saling mengerti. Saling anti dan saling membenci, saling berebut pengaruh adalah salah satu akibat dari tidak adanya saling mengerti dang saling menghargai antara satu dengan yang lain.

Dalam mengembangkan nilai-nilai Pendidikan toleransi di SMA Semen Gresik perlu memperhatikan beberap hal diantaranya; a) Pelaksanaan Pendidikan toleransi tidak boleh pada masalah aqidah; b) Pelaksanaan pendidikan Islam toleransi tidak berada pada wilayah ibadah (ubudiyah); c) Pelaksanaan Pendidikan toleransi tidak dalam hal-hal yang dilarang dalam ajaran. Sedangkan dalam proses pembelajaran pengembangan toleransi terdapat metode yang digunakan diantarnya adalah: metode keteladanan, metode pembiasaan, metode Spontanitas, metode pengkondisian, kegiatan rutinitas, pengintegrasian dalam mata pelajaran.

\section{Daftar Rujukan}

Abdullah, Maskuri. Pluralisme Agama dan Kerukunan dalam Keagamaan. Jakarta: Buku Kompas, 2001.

Akhyar, Zainul. Harpani Matnuh, Siti Patimah. "implementasi Toleransi Antar Umat Beragama Di Desa Kolam Kanan Kecamatan Barambai Kabupaten Barito Kuala”, jurnal Pendidikan Kewarganegaraan, Vol. 5, 2015.

Al-Munawar, Sa'id Agil Husin. Fiqih Hubungan Antar Agama. Jakarta: Ciputat Press.

Al-Qur'an Dan Terjemahanya, Bandung: PT Mizan Pustaka, 2009.

Armai, Arief. Pengantar Ilmu dan Metodologi Pendidikan Islam, Jakarta: Ciputat Pres, 2002.

Ath-Thabhari, Abu Ja'far Muhammad bin Jarir Tafsir Ath-Thabari (23), diterjemahkan dari jami' Al-Bayan an Ta'wil Ayi Al-Qur'an, terj Abdurrahman Supandi, Jakarta:Pustaka Azzam, 2009.

Azwarhadi, "Implementasi, pendidikan Islam, toleransi beragama" Jurnal Manajemen, Kepemimpinan dan Supervisi Pendidikan, Vol. 1, No. 02, 2016.

Azwarhadi, "Implementasi, Pendidikan Islam, Toleransi Beragama" Jurnal manajemen, kepemimpinan dan supervisi pendidikan, Vol. 1, No. 2, Juli-desember 2016.

Bakar, Abu. "Konsep Toleransi beragama dan Kebebasan Beragama" Jurnal, Toleransi Beragama: Media Komunikasi Umat Bergama, Vol. 7, No. 2, 2015.

Basri, Hasan. Filsafat Pendidikan Islam, Bandung: CV Pustaka Setia, 2009.

Bruinessen, Martin Van. "Genealogies of Islamic Radicalism in post-Suharto Indonesia", Southeast Asia Research, No. 2, 2002.

Fachrian, Muhammad Rifqi, Toleransi Antar Umat Beragama dalam Al-Qur'an, Depok: PT Raja Grafindo Persada, 2018.

Islamil, Faisal. Islam, Identitas, Ilahiyah dan Realitas Insaniyah, Yogyakarta: Tiara Wacana Group, 2009.

Farida, Anik dkk. Pendidikan Multikulturalisme di Sekolah Menengah Atas, Jakarta: Kedeputian Bidang Pengembangan SIPTEKNAS Kementerian Riset dan Teknoogi. 2010.

Fuad, Nurhati. "Toleransi beragama pada anak melalui Pendidikan” Societas DEI, Vol. 2, No. 1, April 2015

Hasbullah, Dasar-dasar Ilmu Pendidikan, Jakarta : Rajawali Pers, 2009.

Hasyim, Umar. Toleransi dan kemerdekaan Beragama Dalam Islam sebagai dasar Menuju Dialog dan Kerukunan Antar Agama, Surabaya : PT.Bina Ilmu, 1991. 
Hasyim, Umar. toleransi dan kemerdekaan Beragama Dalam Islam sebagai dasar Menuju Dialog dan Kerukunan Antar Agama, Surabaya : PT.Bina Ilmu, 1991.

Jim ife, Frank Teseriero. 2006. Cumunity Development, Yogyakarta: Pustaka Belajar. Kemendiknas. Bahan Pelatihan Penguatan Metodologi Pembelajaran Berdasarkan NilaiNilai Budaya untuk Membentuk Daya Saing dan Karakter Bangsa, Jakarta: Kementerian Pendidikan Nasional BadanPenelitian dann Pengembangan Pusat Kurikulum, 2010.

Koentjaraningrat, Kebudayaan, Mentalitas dan pembangunan, Jakarta:Gramedia, 1989. Mudlofir, Ali. Modul Pengembangan Profesionalitas Guru, Jakarta: Rineka Cipta. 2011. Nasution, Harun. Islam Rasional Gagasan dan Pemikiran, Bandung: Mizan 1998.

Nazarudin, Manajemen Pembelajaran (Implementasi Konsep, Karakteristik dan Metodologi Pendidikan Agama Islam di Sekolah Umum), Yogyakarta: Teras, 2007.

Nurhadi, Mulyani A. Proceeding International Symposium on The Strategic Role of Religious Education in The Development of Culture of Peace. Jakarta: Centre for Research and Development and Training Ministry of Religious Affairs

Ramayulis, Ilmu Pendidikan Islam, Cet ke-3, Jakarta: Kalam Mulia, 2002.

Shihab, Alwi. Islam Inklusif: Menuju Sikap Terbuka dalam Beragama, Cet. Ke-3, Bandung: Mizan, 1998.

SM, Ismail. Strategi Pembelajaran PAI Berbasis PAIKEM, Semarang: Rasail, 2009.

Suparlan, Pasurdi. Pembentukan Karakter, Bandung: PT Remaja Rosdakarya, 2008.

Suparta, Mundzier. Islamic Multicultural Education, Jakarta: Al Ghazali. 2009.

U. W. Saripudin, Konsep dan Strategi Moral Pancasila di Sekolah Menengah (Penelitian Kepustakaan). Jakarta: Depdikbud Dirjen Dikti. Jurnal visi ilmu pendidikan, Busru Endang Mengembangkan sikap Toleransi dan Kebersamaan di kalangan Siswa. 1998.

Umar Hasyim, Toleransi dan kemerdekaan Beragama dalam Islam Sebagai dasar Munuju Dialog dan Kerukunan Antar Agama, Jakarta: PT. Bina Ilmy, 1978.

Undang-Undang Nomor 20 Tahun 2003 Tentang Sistem Pendidikan Nasional, Pasal 1 Ayat 1 Utami, Siti Rizki. Implementasi Nilai-Nilai Toleransi dalam Lembaga non Muslim, IAIN Salatiga. 2018.

Wibowo, Agus. Pendidikan Karakter-Strategi Membangun Karakter Bangsa Berperadaban, Jakarta: Pustaka Pelajar, 2012.

Yaqin, M. Ainul. Pendidikan Multikultural, Cross-Cultural Understanding untuk Demokrasi dan Keadilan, Yogyakarta: Pilar Media, 2005. 